\title{
An efficient protocol for in vitro propagation of Fig (Ficus carica sp) and evaluation of genetic fidelity using RAPD and ISSR markers
}

\author{
El-Dessoky S. Dessoky ${ }^{1,2}$, Attia O. Attia ${ }^{1,2 *}$, El-Awady A. M. Mohamed ${ }^{1,3}$ \\ ${ }^{1}$ Scientific Research Deanship, Biotechnology Research Unit, Taif University, Taif, KSA. ${ }^{2}$ Department of Plant Genetic Transformation, Agricultural \\ Genetic Engineering Research Institute (AGERI), Agricultural Research Centre (ARC), Giza, Egypt. ${ }^{3}$ Department of Genetics, Faculty of Agriculture, Cairo \\ University, Giza, Egypt.
}

\section{ARTICLE INFO}

\section{Article history:}

Received on: 30/03/2016

Revised on: 18/05/2016

Accepted on: 04/06/2016

Available online: 26/08/2016

Key words:

Micro-propagation, Ficus

carica $s p$, Genetic

homogeneity, RAPD, ISSR.

\begin{abstract}
Fig had been proliferated in vitro using tissue culture techniques. However, factors affecting shoot proliferation have not been optimized. In the present study, sufficient protocol for in vitro propagation of fig trees (Ficus carica $\mathrm{sp}$ ) using shoot tips and nodal explants were reported. High percentage of shoots proliferation (95\%) was obtained by culture of nodal explants containing two buds that were excised from greenhouse plants on MS medium supplemented with $3.0 \mathrm{mg} / \mathrm{l} \mathrm{BAP}$ and $0.1 \mathrm{mg} / \mathrm{l} \mathrm{Kin}$. Multiple shoots (12 multiple shoots per explant) were obtained after subculture of formed shoots on MS medium supplemented with $2.0 \mathrm{mg} / \mathrm{l} \mathrm{BAP}, 0.1 \mathrm{mg} / \mathrm{l} \mathrm{Kin}$ and $0.1 \mathrm{mg} / 1$ Gibberellic acid (GA3). Subsequently, high frequency of rooting $(100 \%)$ were obtained after transferring the plantlets to half strength MS basal medium supplemented with $2.0 \mathrm{mg} / \mathrm{l}$ indole-3-Acetic acid, $0.1 \mathrm{mg} / 1$ Indole butyric acid and $2 \mathrm{~g} / 1$ activated charcoal. Rooted plantlets were planted in pots containing a sterile soil and kept in the green house; the acclimatization was performed successfully with $100 \%$ survival rate. One year old plants were exhibited normal morphological characters comparing with the mother plant. Genetic homogeneity of the micro-propagated plants was evaluated by molecular analysis using nine randomly selected 1 -year-old fig plants along with the mother plant. A total of six RAPD primers and 5 inter-simple sequence repeat (ISSR) primers produced a total of 109 resolvable, reproducible and scorable bands ranging from 250 to $1550 \mathrm{bp}$ in size. Among these bands, 103 bands were monomorphic (94.5\%) and 6 bands were polymorphic (5.5\%). This low polymorphism ration between mother plants and micro-propagated plants indicates the little effect of somaclonal variations, the high genetic similarity between mother plants and micro-propagated plants and demonstrates the reliability of our in vitro propagation system for fig trees.
\end{abstract}

\section{INTRODUCTION}

Fig (Ficus carica L.) is a deciduous tree belonging to the Moraceae family [1] which grows in many different environments and soil types [2]. It is recognized to essay the adeptness to linger predominant shortfall and blend salinity highlight [3] making it a suitable species for cultivation in semiarid environments such as the Mediterranean and middle-East. Fig tree plantations cover 426.244 hectare area worldwide with an overall yield of 1.070.676 million tones [4]. Turkey, Egypt, Iran are the largest fig producing countries that using the

\footnotetext{
* Corresponding Author
}

Emai: attiaattia7@yahoo.ca vegetative propagated plants, especially by the rooting of cuttings. However, the propagation by conventional method of cuttings, grafting and layering is slow and limited and results in poor rooting and only $20-30 \%$ of the cuttings survive [5]. In addition, these methods contributed significantly to the dissemination of pathogens which affect the yield potential of the crop. Figs have been restricted to producing Fig-mosaic-virus-free plants by singleshoot-tip elongation [6]. Hence, in vitro micro-propagation of Ficus species has been widely studied as an alternate method for mass-scale production of high quality planting material being a faster multiplication technique in comparison with meristem culture [7-10]. Only a limited number of reproducible regeneration methods have been reported and most of the successful results were obtained from using shoots tip and apical buds [5, 11]. 


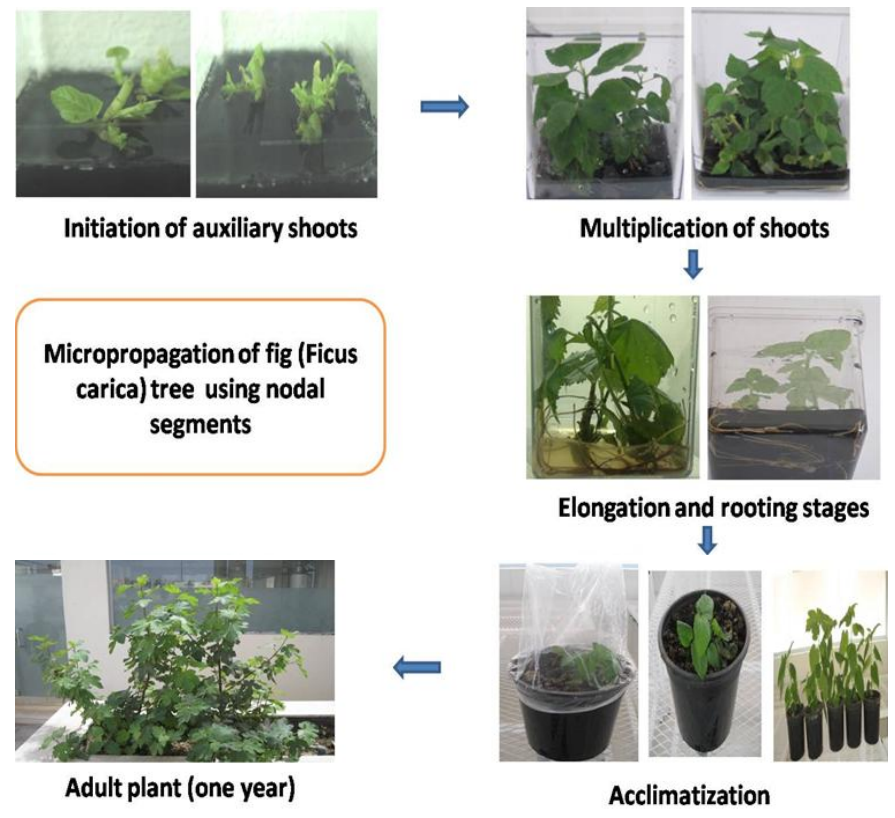

Fig 1: In vitro propagation of fig tree (Ficus carica sp).

Effect of different factors like growth regulators on the in vitro shoot proliferation has also been evaluated. A feasible protocol for shoot proliferation of $F$. carica 'Gular' by growing on MS medium supplemented with $2.0 \mathrm{mg} / \mathrm{l}$ benzyladenine (BA) and $0.2 \mathrm{mg} / 1$ naphthaleneacetic acid (NAA) has been reported [5,12]. A similar method was also tested for F. carica 'Roxo de Valinhos' with higher levels of BA and lower levels of NAA [10], but results were less promising. Although the propagation fig using tissue culture techniques has several potential advantages over conventional propagation method like high multiplication rate in short time, season-independent production of plants, production of disease-free plant and germplasm conservation [13], the maintenance of true-to-type nature of the in vitro propagated plants is an important requisite for upholding certain agronomic and horticultural traits when using elite genotype. It has been reported that tissue culture environment and influence of culture conditions like culture media, type of explant, successive transfer of culture, temperature, $\mathrm{pH}$ etc. cause alterations in cellular controls, resulted genomic changes in the in vitro raised plantlets $[14,15]$. While, plantlets regenerated through enhanced axillary branching or direct somatic embryogenesis has been reported to be genetically uniform [14], the possibility of somaclonal variations cannot be ruled out completely [16]. Thus, the genetic stability of in vitro propagated plants should be assessed as early as possible especially in long living woody trees, so that the deleterious effects that might be expressed later in growth do not result in having a severe economic impact [17]. The genetic fidelity of in vitro raised plants has been assessed using several strategies $[18,19]$. Previously, some workers have been used isozyme electrophoresis for evaluation of genetic integrity of in vitro raised plants, but the effects of environmental and developmental variation on it is one of the major drawbacks in its widespread use [20]. Recently, DNA-based molecular markers have served as an important tool to assess the true to type nature and genetic homogeneity of the micro-propagated plants Restriction fragment length polymorphism (RFLP) and Amplified fragment length polymorphism (AFLP) are shown to be reliable for screening of genetic fidelity in tissue cultured plants, but the risk of using radioactive labeling, extensive care and using the high cost make it unsuitable for genetic fidelity testing purposes [21]. Randomly Amplified Polymorphic DNA (RAPD) markers have been used for assessment of genetic fidelity of in vitro propagated plants in many reports [21-24]. In recent years, ISSR markers have been proved to be more efficient than dominant RAPD markers for the detection of somaclonal variations in tissue culture plants [16]. Many reports were documented the assessment of genetic fidelity of micropropagated plants using microsatellite markers [16, 17, 25-28 ] and ISSR markers [21,23,29-33]. In tree species, assessment of genetic stability of tissue culture raised plants through molecular markers at early stage is desirable as morphological variations in these plants can be detected usually only at maturity and fruiting stage [34]. Therefore, the aims of the present study were to establish an in vitro shoot proliferation protocol for the important KSA variety of $F$. carica, assess the applicability of RAPD and ISSR markers for determining genetic stability of in vitro regenerated plants and the reliability of developed micro-propagation protocol for true to type cloning. The results may lead to the development of a protocol for rapid shoot proliferation, which can supplement the conventional method of cuttings.

\section{MATERIALS AND METHODS}

\subsection{Plant material}

Healthy shoot tips and nodal explants were collected from greenhouse of Ficus carica L. Explants were washed first under running tap water for $30 \mathrm{~min}$, to remove the superficial dust followed by immersion in $70 \%$ ethanol for $1 \mathrm{~min}$, then incubated in $15 \%$ Clorox (5.25\% of sodium hypochlorite) for $12 \mathrm{~min}$ and rinsed for three times with sterile distilled water and rinsed with sterile anti-oxidant solution (0.01\% L-ascorbic acid).

\subsection{Culture conditions}

The sterilized nodal cuttings containing axillary buds were transferred to shoot initiation media containing full strength MS medium (4.4 g/l+30 g/l sucrose) and supplemented with different concentrations and combinations of auxins and cytokinins. all media was adjusted to $5.7 \mathrm{pH}$ using $1.0 \mathrm{~N}$ hydrochloric acid $(\mathrm{HCl})$ or $1.0 \mathrm{~N}$ potassium hydroxide $(\mathrm{KOH})$, before adding $8 \mathrm{~g} / 1$ plant agar. Media were autoclaved for $20 \mathrm{~min}$. at $121^{\circ} \mathrm{C}$ and $1.5 \mathrm{k} / \mathrm{cm}^{2}$ pressure. All in vitro cultures were placed on a 16/8 hour light/dark cycle in a culture room maintained at 26 $\pm 2^{\circ} \mathrm{C}$

\subsection{Micro-propagation stages}

For shoot initiation, nodal cuttings containing axillary buds explants were cultured on shoot initiation media containing full strength MS medium with various concentrations of BAP and 
Kin. for four weeks. Shoot multiplication and elongation stages were performed by sub-culturing of proliferated shoots on MS media sublimated with different combined concentrations of BAP, Kin and Gibberellic acid (GA3). For rooting stage, shoots $(5-6 \mathrm{~cm}$ length) were transferred in half strength Murashige and Skoog (MS) medium supplemented with different combinations and concentrations of IAA and IBA for four weeks and containing 2 $\mathrm{g} / \mathrm{l}$ activated charcoal. Rooted explants were planted in pots containing a sterile soil and kept in the green house for acclimatization.

\subsection{Statistical analysis}

Statistical analysis of data, analysis of variance (ANOVA) and mean separation were carried out using Duncan's multiple range test and significance was determined at the ( $\mathrm{p}<$ $0.01)$ level. Data analysis was performed using ASSISTAT Version 7.7 beta (2015).

\subsection{Isolation of genomic DNA for molecular markers analysis}

Fresh young healthy leaves were collected and grounded to powder with liquid $\mathrm{N}_{2}$ using a mortar and pestle. Genomic DNA was isolated from leaf samples using the procedure described by the plant isolation kit (Jena Bioscience, Germany).

\subsubsection{RAPD analysis}

PCR reaction and condition: Sequence of the six RAPD random primers that used to detect the polymorphism and produce a clear scoriable and reproducible banding pattern is shown in (Table 1). The amplification reactions were performed in a $25 \mu \mathrm{l}$ volume containing about $30 \mathrm{ng}$ genomic DNA and $300 \mathrm{pg}$ random primer (Operon Technologies Inc.) using $12.5 \mu \mathrm{l}$ of $2 \mathrm{x}$ green master mix (Promega) in Bio-Rad C1000 thermal cycler (Germany). The PCR temperature profile was adjusted as $5 \mathrm{~min}$ at $94^{\circ} \mathrm{C}$ for initial denaturation followed by 40 cycles of $60 \mathrm{~s}$ at $94^{\circ} \mathrm{C}$, an annealing step of $1 \mathrm{~min}$ at $37^{\circ} \mathrm{C}$ and an elongation step of $1 \mathrm{~min}$ at $72^{\circ} \mathrm{C}$; and finally a $7 \mathrm{~min}$ extension at $72^{\circ} \mathrm{C}$ was applied. Electrophoresis in a 1, 5\% agarose gel containing ethidium bromide $(0.5 \mu \mathrm{g} / \mathrm{ml})$ in $1 \mathrm{X}$ TBE buffer at 95 volts was used for the separation of the amplification products. Subsequently, the separated PCR products were visualized on UV light and photographed using a gel documentation system (Bio-Rad® Gel Doc-2000).

Table 1: Effect of different concentrations and combinations of BAP and Kin on shoot formation of Fig Tree (Ficus carica $\mathrm{sp}$ ).

\begin{tabular}{cccc}
\hline \multicolumn{2}{c}{ Supplement $(\mathbf{m g} / \mathbf{l})$} & No. of explants & $\begin{array}{c}\text { Shoot proliferation } \\
(\boldsymbol{\%})\end{array}$ \\
\hline BAP & Kin & 40 & $9 \mathrm{~d}$ \\
0.0 & 0.0 & 40 & $58 \mathrm{c}$ \\
.0 & 0.3 & 40 & $70 \mathrm{~b}$ \\
2.0 & 0.2 & 40 & $95 \mathrm{a}$ \\
3.0 & 0.1 & & \\
\hline
\end{tabular}

Each treatment consisted of 3 replicate in which 40 explants were used. The averages followed by the same letter do not differ statistically between themselves at $(\mathrm{p}<.01)$.

\subsubsection{ISSR analysis}

Ten ISSR primers were tested using a specific and optimal annealing temperature for each one (Table 2). PCR reactions were performed in a total volume of $20 \mu \mathrm{l}$ using the BioRad C1000 thermal cycler (Germany).

Table 2: Effect of different concentrations and combinations of BAP, Kin and GA3on multiplication and elongation of Fig Tree (Ficus carica sp.).

\begin{tabular}{ccccc}
\hline \multicolumn{2}{c}{ Supplement $(\mathbf{m g} / \mathbf{l})$} & $\begin{array}{c}\text { No. of shoots / } \\
\text { explants }\end{array}$ & $\begin{array}{c}\text { Elongated shoots } \\
\text { (\%) }\end{array}$ \\
\hline BAP & GA3 & Kin & & $30 \mathrm{c}$ \\
0.0 & 0.0 & 0.0 & 2 & $50 \mathrm{bc}$ \\
1.0 & 0.1 & 0.1 & 5 & $70 \mathrm{ab}$ \\
2.0 & 0.1 & 0.1 & 8 & $90 \mathrm{a}$ \\
\hline
\end{tabular}

Each treatment consisted of 3 replicate in which 30 explants were used. The averages followed by the same letter do not differ statistically between themselves at $(\mathrm{p}<.01)$

The reaction mixture contained $60 \mathrm{pg}$ of each primer, 100 $\mu \mathrm{M}$ of each deoxinucleotide, 0.5 units of GoTaq polymerase (Promega), 10×Taq buffer containing $2.5 \mathrm{mM} \mathrm{MgCl}_{2}$ and $10 \mathrm{ng}$ of template DNA. Amplification reaction condition was $94^{\circ} \mathrm{C} / 5 \mathrm{~min}$, followed by 30 cycles of $94^{\circ} \mathrm{C} / 1 \mathrm{~min}, 4-60^{\circ} \mathrm{C}$ (specific for each primer) $/ 1$ min and $72^{\circ} \mathrm{C} / 2$ min and ending with an extension step of $7^{\circ} \mathrm{C} / 7 \mathrm{~min}$. PCR products were analyzed using agarose $(2 \%$ w/v) electrophoresis gels stained with ethidium bromide and only bands with high intensity and well separated were selected.

\subsubsection{Data scoring and statistical analysis}

To ensure the absence of artifacts, bands were carefully selected from replicated amplifications (three times). Amplified bands designated by their primer code and their size in base pairs. Data recorded as discrete variables: 1 for the presence and 0 for the absence of a similar band. Only intense and reproducible bands appearing on the gel were scored. Band scoring was analyzed using Gene Tools-gel analysis software of SPSS ver. 16.

\section{RESULTS}

\subsection{Optimization of Figs micro-propagation protocol}

The shoot tips and nodal explants were incubated on MS medium without Plant Growth Factors or fortified with different concentrations of BAP $(0.0,1.0,2.0$ and $3.0 \mathrm{mg} / \mathrm{l})$ with $(0.0,0.1$, 0.2 or $0.3 \mathrm{mg} / \mathrm{l}$ ) Kin. The results are summarized in (Table 1). The axillary bud initiation was observed in all medium used after two to three weeks. Increase of BAP and decrease in kin concentrations resulted in a gradual increase in the shoot formation frequency. However, the best frequency of break of axillary buds was achieved in MS medium supplemented with $3 \mathrm{mg} / \mathrm{l} \mathrm{BAP}$ and $0.1 \mathrm{mg} / \mathrm{l} \mathrm{Kin}$. At this concentration, the best percentage of explants (95\%) showed shoot initiation and more significance comparing with other concentrations used at the $(\mathrm{p}<0.01)$ (Table 1). Multiple shoots were emerged directly from axillary nodes of the cultured explants after four weeks in medium containing different concentrations of BAP with combination with Kin and GA3 (Table 2). 
The medium supplemented with a combination of $2,0.1$ and $0.1 \mathrm{mg} / \mathrm{l}$ of BAP, Kin and GA3, respectively, was found to be the ideal concentration to induce maximum shoots (12) per nodal explant (Table 2). In addition, subculture in the same medium resulted in the best shoots elongation frequency (90\%), however, shoots elongation was recorded in all the medium-used. For root formation, the in vitro regenerated shoots were excised aseptically and implanted on half strength MS medium with growth regulators IAA and IBA. Rooting was recorded only when half strength MS medium was used in combination with different concentrations of IBA and IAA (Table 3).

Table 3: Effect of different concentrations and combinations of IAA and IBA on root formation of Fig Tree (Ficus carica $\mathrm{sp}$ ).

\begin{tabular}{|c|c|c|c|}
\hline \multicolumn{2}{|c|}{ Supplement (mg/l) } & \multirow{2}{*}{ No. of shoots } & \multirow{2}{*}{ Rooted shoots (\%) } \\
\hline IAA & IBA & & \\
\hline 0.0 & 0.0 & 30 & $00 \mathrm{e}$ \\
\hline 0.5 & 2.0 & 30 & $40 \mathrm{~d}$ \\
\hline 1.0 & 1.0 & 30 & $80 \mathrm{bc}$ \\
\hline 1.5 & 0.5 & 30 & $90 \mathrm{ab}$ \\
\hline 2.0 & 0.1 & 30 & $100 \mathrm{a}$ \\
\hline
\end{tabular}

Each treatment consisted of 3 replicate in which 30 explants were used. The averages followed by the same letter do not differ statistically between themselves at $(\mathrm{p}<.01)$.

Induction of roots was noticed after 20 days of implantation in all medium. Rooting frequency of 40, 80 and $90 \%$ was obtained on the concentrations of 0.5 and 2,1 and $1,1.5$ and $0.5 \mathrm{mg} / \mathrm{l}$ IAA and IBA respectively ( $<<0.01$; Table 3$)$. However, the concentration of $2 \mathrm{mg} / \mathrm{l}$ IAA and 0.1 IBA was found optimal with best rooting formation $(100 \%)$. For acclimatization, rooted plantlets were planted in pots containing a sterile soil (peat moss and sand) and kept in the green house. The adaptation was performed successfully with $100 \%$ survival rate.

\subsection{Genetic fidelity of micro-propagated plants}

Out of the 16 screened primers of RAPD and ISSR that used to assess the genetic stability in nine randomly selected oneyear old micro-propagated plants along with the mother plant, 14 produced resolvable, reproducible and scorable bands (Table 4 and Table 5).

Table 4: List of random primers that have been used for RAPD analysis, numbers of amplicons and \% polymorphism.

\begin{tabular}{ccccc}
\hline PN & PS & NA & NPB & P\% \\
\hline OPA-01 & 5'-CAGGCCCTTC-3' & 10 & 1 & 10.00 \\
OPA-03 & 5'-AGTCAGCCAC -3' & 7 & 0 & 00.00 \\
OPA-07 & 5'-GAAACGGGTG-3' & 5 & 0 & 00.00 \\
OPA-10 & 5'-GTGATCGCAG-3' & 4 & 0 & 00.00 \\
OPB-03 & 5'-CATCCCCCTG -3' & 12 & 1 & 08.30 \\
OPH-05 & 5'-AGTCGTCCCC-3' & 7 & 1 & 14.30 \\
Total & & 45 & 3 & 06.60 \\
\hline
\end{tabular}

PN: Primer Name, PS: Primer sequence, NA: No. of amplicons, NPB: No. of polymorphic bands and P\%: Polymorphism\% .

Table 5: List of ISSR primers that have been used for ISSR analysis, numbers of amplicons and \% polymorphism.

\begin{tabular}{cccccc}
\hline PN & PS & AT & NA & NPB & P $\%$ \\
\hline ISSR-06 & (AC)8YT & 49.0 & 06 & 0 & 0.00 \\
ISSR-07 & HBH(AG)7 & 50.0 & 12 & 1 & 8.30 \\
ISSR-08 & BHB(GA)7 & 52.0 & 10 & 1 & 10.00 \\
\hline
\end{tabular}

\begin{tabular}{cccccc}
\hline ISSR-10 & BDB(AC)7 & 50.0 & 12 & 1 & 8.30 \\
ISSR-11 & (AG)8T & 50.0 & 13 & 0 & 0.00 \\
ISSR-12 & (AG)8C & 48.5 & 03 & 0 & 0.00 \\
ISSR-13 & (AG)8G8 & 48.5 & 04 & 0 & 0.00 \\
ISSR-15 & (GA)8C & 48.5 & 04 & 0 & 0.00 \\
Total & & & 64 & 3 & 4.70 \\
\hline
\end{tabular}

PN: Primer Name, PS: Primer sequence, AT: Annealing Temperature, NA: No. of amplicons, NPB: No. of polymorphic bands and P: Polymorphism\% .

Total of 109 bands were obtained from the two markers in which only 6 bands were polymorphic representing 5.5\% polymorphism. In RAPD analysis, six primers produced 45 bands with $6.6 \%$ polymorphism ( 3 bands). Number of bands produced by the six primers was ranged between 4 and 12 with average of 7.5 bands per primers. The three polymorphic bands were produced by the 3 primers OPA-01, OPB-03 and OPH-05 as one band for Each that represent $10 \%, 8.3 \%$ and $14 \%$ of the total bands produced by them, respectively (Table 4). The other three primers $(50 \%)$ showed $100 \%$ monomorphic pattern. The banding pattern produced by the primers OPA- 01, OPH- 05 and OPA-03 are shown in (Fig. 2).

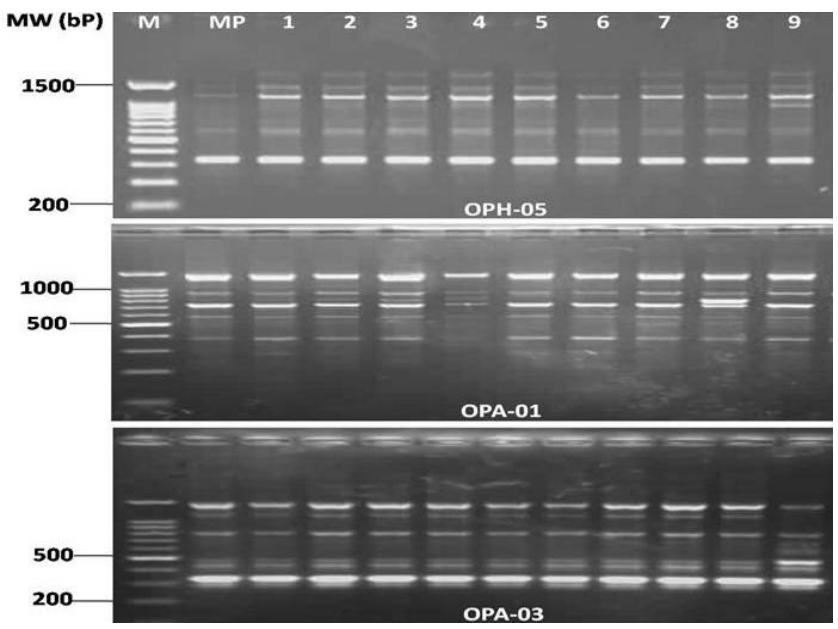

Fig. 2: RAPD profile of mother plant and in vitro raised plants of Fig Tree (Ficus carica $\mathrm{sp}$ ) using three random primers.

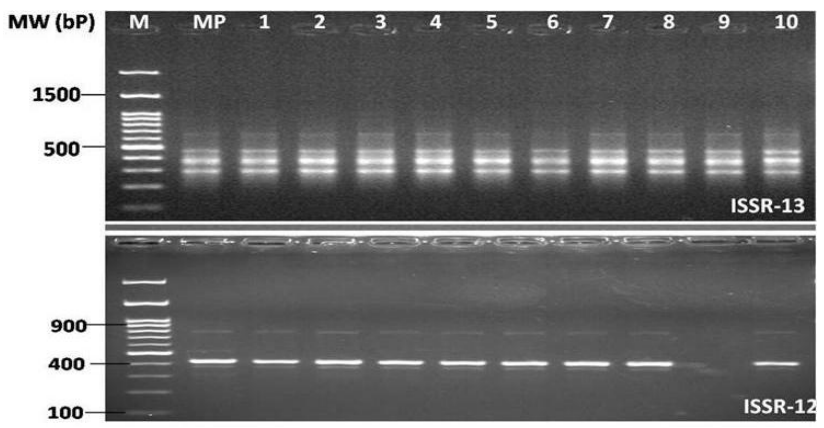

Fig 3: ISSR profile of mother plant and in vitro raised plants of Fig Tree (Ficus carica sp) using primers ISSR-12 and ISSR-13.

In ISSR analysis, eight primers produced 64 bands with $4.7 \%$ polymorphism ( 3 bands). Number of bands produced by the eight primers was ranged between 3 and 13 with average of 8 
bands per primers (Table 5). Each of the three primers ISSR-7, ISSR- 8 and ISSR-10 produced one polymorphic band among the total bands produce by each of them (Table 5).

While, all the bands produced by the other five primers ISSR-6 and ISSR-11, ISSR-12, ISSR-13 and ISSR-15 was monomorphic (Table 5). ISSR amplification pattern (Fig. 3) obtained with the two primers ISSR-12 and ISSR-13 (with 100\% monomorphic pattern).

\section{DISCUSSION}

Development of efficient and reproducible protocol for micro-propagation of tree species has many advantages, however, morphological variations in these tissue culture raised plants can be detected usually only at maturity and fruiting stages, therefore assessment of genetic reliability in these plants through molecular markers at early stage is desirable before their exploitation for routine propagation. In the present study, an efficient protocol for mass production of the fig trees using the nodal explants was developed (Fig. 1). Deferent combinations of the two cytokinins BAP and Kin were used for break of axillary buds and shoots proliferation. In the presence of $0.5 \mathrm{mg} \mathrm{BA}$, the shoots of some fig cultivars such as 'Bermuda' and 'Lampa' proliferated well [35]. However, the presence of Kin alone in the medium did not support good callus proliferation of fig [36]. At lower concentrations of cytokinin, lateral buds from the base of the leaves grew into individual shoots (Fig. 1); however, increasing BAP concentration to $3 \mathrm{mg} / \mathrm{l}$ and $0.1 \mathrm{mg} / \mathrm{l} \mathrm{Kin} \mathrm{resulted} \mathrm{in} \mathrm{the} \mathrm{best} \mathrm{frequency} \mathrm{of} \mathrm{break}$ of axillary buds (95\%) and adventitious shoot proliferation (Table 3). Further increases in cytokinin concentration to $6.0 \mathrm{mg} / 1$, resulted in a decreased proliferation rate. Similar results were observed in sprouting of apical buds on MS medium with the same combination of BAP and Kin. Fráguas et al. [37] showed that, the regulator strength of (Woody Plant Medium) WPM in combination with $0.5 \mathrm{mg} / \mathrm{l} \mathrm{Kin}$ was the best condition for shoot proliferation of fig "Roxo de Valinhors" plants. It was indicated that, BA stimulated shoot proliferation and multiplication of Morus alba cv. Kokoso and Moritiana [38].

Increasing the number of shoots regenerated from the explant with increases in BAP concentration in the medium combined with stable concentration of GA3 and Kin with BAP at $5.0 \mathrm{mg} / \mathrm{l}$, the number of shoots regenerated from the single explants decreased, which indicated that BAP had an adverse effect when used at a higher than optimal concentration. Proliferation behavior of BAP in banana was observed [39]. The positive role of BAP on micro-propagation stage might be due to cytokinins great role in releasing lateral buds from the dominance of terminal buds without need to remove the apical bud by promoting the formation of xylem tissues of buds which will facilitate the transformation of water and nutrients leading to lateral bud growth [40] as well as, the important role of cytokinins in increasing the synthesis of RNA, proteins and enzymes inside the cell which enhance bud growth as well $[41,42]$. It has been reported that improvement in the shoot quality of fig can be achieved by culturing explants on medium containing $3.0 \mathrm{mg}$ activated charcoal [43]. Percentage of a survival rate was (100\%) when rooted plantlets were transfer to pots containing a sterile soil and kept in the green house. Hemaid et al. [44] reported that, the percentage of acclimatized fig plants was high (95-97\%) and was obtained in two months. A similar method has been reported by Pontis and Melas [45], for acclimatization of Ficus carica L. The one-year old micro-propagated trees were found to be phenotypically normal and essentially identical with their mother plant which partly suggests the minimal or absence of somaclonal variations. The two molecular markers (RAPD and ISSR) were used to test these results at the molecular level. The usages of two markers, which amplify different regions of the genome, allow better chances for the identification of genetic variations in the clones [46]. Palombi and Damiano [47] suggested the use of more than one DNA amplification technique as advantageous in evaluating somaclonal variation on micro-propagated plants of kiwi fruit.

The random nature of RAPD and the fact that a simple sequence repeat targets the fast evolving hyper variable sequences makes these two markers suitable to detect variations among micro-propagated plants $[25,48]$. The high ratio of monomorphic banding pattern in micro-propagated and mother plant and the law frequency of polymorphism in RAPD and ISSR profile of micropropagated plantlets (6.6 and 4.7, respectively) suggested the occurrence of little effects of somaclonal variations.

There are many reports in literature suggested that, plants regenerated through organized tissues like meristems or direct somatic embryogenesis maintain genetic integrity of the plantlets with a least risk of genetic variation [14,46,48,49]. This founding further supports the fact that the axillary multiplication is the safest mode of micro-propagation to produce true to type progeny. In addition, these results confirm the high genetic homogeneity of the in vitro raised plants and also indicated that the developed micropropagation protocol is efficient enough to maintain genetic stability. Similar results were reported by Srivastava et al. [50] who evaluated $<6 \%$ frequency polymorphism of in vitro raised sugarcane varieties produced from shoot-tip culture through RAPD markers.

\section{CONCLUSION}

In conclusion, the obtained results representing an efficient protocol for the mass production of figs tree and indicated good genetic fidelity obtained in the in vitro raised plantlets when examined by the two markers system. Hence we concluded that, the developed protocol could be effectively used for rapid micropropagation and commercial utilization of figs without much risk of genetic instability.

\section{REFERENCES}

1. Vallejo F, Marin J, Tomas-Barberan F. Pheolic compound content of fresh and dried figs, Ficus carica L.) Food Chemist. 2012; 130:485492. 
2. Vemmos S, Petri E, Stournaras V. Seasonal changes in photosynthetic activity and carbohydrate content in leaves and fruit three fig cultivars (Ficus carica L.), Sci Hortic. 2013; 160:198-207.

3. Golombek SD, Ladders P. Effects of short term salinity on leaf gas exchange of the fig (Ficus carica L.). Plant Soil. 1993;148:21-27.

4. Pasqual M, Ferreira EA. Micro-propagation of Fig Tree (Ficus carica sp). In:Mohan JS, Häggman,editors. Protocols for Micro-propagation of Woody Trees and Fruits, Dordrecht, The Netherlands, Published by Springer; 2007; p. 409-416.

5. Kumar V, Radha A, Kumar CS. In vitro plant regeneration of fig (Ficus carica L. cv. Gular) using apical buds from mature trees, Plant Cell Rep. 1998; 17:717-720.

6. Muriithi LM, Rangan $\mathrm{T}$ S, Waite $\mathrm{BH}$. In vitro propagation of Fig through shoot tip culture, Hortic Sci. 1982;17:86-87.

7. Guerra M, Costa RMBFL. Propagação da figueira 'Roxo de Valinhos', através da cultura de meristemas, Congr Bras Frut. 1987; p. 465-467.

8. Barbosa W, Campo-Dall'Orto FA, Ojima M, Martins FP, Bovi V, Castro JL. Produção mudas da figueira 'Roxo de Valinhos' através da cultura in vitro, O Agronômico. 1992; 44:6-18.

9. Anjos Sobrinho A, dos M, Pasqual, Paiva PD, de O. Efeito de diferentes concentrações de BA sobre o desenvolvimento 'in vitro' de gemas apicais de figo, Congr Bras Frut. 1998; p. 347.

10. Brum GR, Micro-propagação da figueira (Ficus carica L.) 'Roxo de Valinhos'. M.Sc. thesis, University of Lavras, Brazil, 2001.

11. Hepaksoy S, Aksoy U. Propagation of Ficus carica L. clones by in vitro culture, Bio Plantarum. 2006; 50: 433-436.

12. Murashige T, Skoog F. Arevised medium for rapid growth and bioassays with tobacco tissue cultures, Physiol Plant. 1962; 15:473-79.

13. George EF, Debergh PC. Micro-propagation: uses and methods. In: George EF et al. editors. Plant Propagation by Tissue Culture (edn 3), 2008; p. 29-64.

14. Rani V, Raina SN. Genetic fidelity of organized meristem-derived micro-propagated plants: a critical reappraisal, In Vitro Cell Dev Biol - Plant. 2000; 36:319-330.

15. Jain SM. Tissue culture-derived variation in crop improvement, Euphytica. 2001;118:153-166.

16. Nookaraju A, Agrawal DC. Genetic homogeneity of in vitro raised plants of grapevine cv. Crimson Seedless revealed by ISSR and microsatellite markers, S Afr J Bot. 2012; 78:302-306.

17. Marum L, Rocheta M, Maroco J, Oliveira MM, Miguel C. Analysis of genetic stability at SSR loci during somatic embryogenesis in maritime pine (Pinus pinaster), Plant Cell Rep. 2009; 28:673-682.

18. Breiman A, Flisenburg T, Galun E. Is Nor region variability in wheat invariably caused by tissue culture. Theoret Appl Genet. 1989; 77:809814.

19. Chowdhury MKU, Vasil JK. Molecular analysis of plants regenerated from embryonic cultures of hybrid sugarcane cultivars (Saccharum spp.). Theoret Appl Genet. 1993; 86:181-188.

20. Rani V, Parida A, Raina SN. Random amplified polymorphic DNA (RAPD) markers for genetic analysis in micropropagated plants of Populus deltoides Marsh, Plant Cell Rep. 1995; 14:459-462.

21. Kumar N, Vijay Anand KG, Reddy MP. In vitro regeneration from petiole explants of non-toxic Jatropha curcas, Ind Crop Prod. 2011; 33:146-151.

22. Asthana P, Jaiswal VS, Jaiswal U. Micro-propagation of Sapindus trifoliatus L. and assessment of genetic fidelity of micro-propagated plants using RAPD analysis, Acta Physiol Plant. 2011; 33:1821-1829.

23. Bhatia R, Singh KP, Sharma TR, Jhang T. Evaluation of the genetic fidelity of in vitro propagated gerbera (Gerbera jamesonii Bolus) using DNA-based markers, Plant Cell Tiss Org. 2011; 104:131-135.

24. Singh SK, Rai MK, Sahoo L. An improved and efficient micropropagation of Eclipta alba through transverse thin cell layer culture and assessment of clonal fidelity using RAPD analysis. Ind Crop Prod. 2012; 37:328-333

25. Rahman MH, Rajora OP. Microsatellite DNA somaclonal variation in micro-propagated trembling aspen (Populus tremuloides), Plant Cell Rep. 2001; 20:531-536.

26. Bennici A, Anzidei M, Vendramin CG. Genetic stability and uniformity of Foeniculum vulgare Mill. regenerated plants through organogenesis and somatic embryogenesis, Plant Sci. 2004; 166: 221 27.

27. Lopes T, Pinto G, Loureiro J, Costa A, Santos C. Determination of genetic stability in long-term somatic embryogenic cultures and derived plantlets of cork oak using microsatellite markers, Tree Physiol. 2006; 26:1145-1152.

28. Brito G, Lopes T, Loureiro J, Rodriguez E, Santos C. Assessment of genetic stability of two micro-propagated wild olive species using flow cytometry and microsatellite markers, Tree Struct Funct, 2010; 24:723-732

29. Aggarwal D, Kumar A, Reddy MS. Shoot organogenesis in elite clones of Eucalyptus tereticornis, Plant Cell Tiss Org. 2010; 102: 4552 .

30. Bhattacharya S, Bandopadhyay TK, Ghosh PD. Somatic embryogenesis in Cymbopogon pendulus and evaluation of clonal fidelity of regenerants using ISSR marker, Sci Hortic. 2010; 123:505-513.

31. Bhatia R, Singh KP, Jhang T. Assessment of clonal fidelity of micropropagated gerbera plants by ISSR markers, Sci Hortic. 2009; 119:208-211.

32. Carrara P, Stano P, Luisi PL. Giant vesicles 'colonies': a model for primitive cell communities, Chem Bio Chem. 2012; 13:1497-1502.

33. Wang X, Sun D, Wang F, Li B, Wu S. The ultrafine component record from the late Cenozoic sequence in the central Tarim basin and its palaeoclimatic implication, Mar. Geol Quatern Geol. 2012; 32:143151.

34. Rai MK, Phulwaria M, Harish, Gupta AK, Shekhawat NS, Jaiswal U. Genetic homogeneity of guava plants derived from somatic embryogenesis using SSR and ISSR markers, Plant Cell Tiss Organ Cult. 2012; 111:259-264.

35. Nobre Ja, Romano A. In vitro cloning of Ficus carica L. adult trees, Acta Hortic. 1998; 480:161-164.

36. Jordan M, Iturriaga L. Formación de raices en entrenudos de higuera (Ficus carica L. cv. Adriatic) cultivados in vitro, Ciencia Inv Agri. 1980; 7:149-151.

37. Fráguas C, Pasqual M, Dutra L \& Cazetta J, Micro-propagation of fig (Ficus carica L.) 'Roxo De Valinhos' plants, In Vitro Cell Dev Biol Plant. 2004; 40: 471-474.

38. Taha HS , Bekheet SA, Saker MM. Factors affecting in vitro multiplication of date palm, Biol Plantarum. 2001; 44:431-433.

39. Soumendra KN, Pattnaik S, Chand PK. High frequency axillary shoot proliferation and plant regeneration from cotyledonary nodes of pomegranate (Punica granatum L.), Sci Hortic. 2000; 85:261-270.

40. Mohammed AA, Al-Younis MA. Fundamentals of Plant Physiology (In Arabic),Third part .College of Agriculture. Baghdad Univ, IRAQ, 1991.

41. Al-Rifae'e MAT, Al-Shobaki SA. Twenty One Century Techniques for Plant Improvement by Tissue Culture, Cairo: Dar Al-Fikr AlArabi, (In Arabic), 2002.

42. Toma RS, Rasheed KA. In vitro propagation through seed culture and regeneration of Asparagus densiflorus L. through callus cultures derived from hypocotyls, Int. J. Pure Appl Sci Technol. 2012; 9:94102 .

43. Barbosa MHP, Jebp P, Capb P, Innecco R. In vitro propagation of Gerbera jamesonii Bolus ex Hook cv. Applebloesem using young capitulums, Revista Ceres. 1994; 41:386-395.

44. Hemaid S, Mahdia G, Naglaa A. Efficient transformation and regeneration of fig (Ficus carica L.) via somatic embryogenesis . GM Crops and Food. 2010; 1:42 - 53.

45. Pontikis CA, Melas P. Micro-propagation of Ficus carica L, Hort Sci. 1986; 21:153.

46. Martins M, Sarmento D, Oliveira MM. Genetic stability of micropropagated almond plantlets, as assessed by RAPD and ISSR markers, Plant Cell Rep. 2004; 23:492-496.

47. Palombi M, Damiano V. Comparison between RAPD and SSR molecular marker in detecting genetic variation in kiwi fruit (Actindia deliciosa A. Chev), Plant Cell Rep. 2002; 20:1061-1066.

48. Joshi P, Dhawan V. Assessement of genetic fidelity of micropropagated Swertia chirayita plantlets by ISSR marker assay, Biol Plant. 2007; 5:22-26. 
49. Carvalho CHS, Zehr UB, Gunaratna N, Anderson J, Kononowicz HH, Hodges TK, Axtell JD. Agrobacterium-mediated transformation of sorghum: factors that affect transformation efficiency, Genet Mol Biol. 2004; 27:259-269.

50. Srivastava S, Jain R, Gupta PS, Singh J. Genetic stability of in vitro raised Sugarcane plantlets by RAPD markers Plant, Cell Biotechnol Molecul Biol. 2006; 7:93-96.

\section{How to cite this article:}

El-Dessoky S. Dessoky, Attia O. Attia, El-Awady A. M. Mohamed., An efficient protocol for in vitro propagation of Fig (Ficus carica sp) and evaluation of genetic fidelity using RAPD and ISSR markers. J App Biol Biotech. 2016; 4 (04): 057-063. DOI: $10.7324 / \mathrm{JABB} .2016 .40406$ 